\title{
NAWIERZCHNIE OBNIŻAJĄCE HAŁAS DROGOWY - DOŚWIADCZENIA KRAJOWE I KIERUNKI ROZWOJU
}

\author{
Klaudia Załęska-Dobkowska, Karol J. Kowalski® ${ }^{\bowtie}$ Jan Król, Piotr Radziszewski, \\ Michał Sarnowski
}

Wydział Inżynierii Lądowej, Politechnika Warszawska, Warszawa

\begin{abstract}
STRESZCZENIE
Hałas drogowy jest istotnym problemem w zakresie ochrony przyrody i planowania rozwoju sieci drogowej. Oprócz napędu i aerodynamiki pojazdu ma on swoje źródło również w oddziaływaniu opony pojazdu z nawierzchnią drogi, szczególnie przy prędkości pojazdów wyższej niż $50 \mathrm{~km} \cdot \mathrm{h}^{-1}$. Stosowanie odpowiednich rozwiązań materiałowo-technologicznych może w znaczącym stopniu obniżyć hałas powstający podczas toczenia pojazdów. W tym celu wykonuje się warstwy ścieralne nawierzchni drogowych z mieszanek mineralno-asfaltowych typu mastyks grysowy (SMA) o drobnym uziarnieniu, o zwiększonej zawartości wolnych przestrzeni (SMA-LA i BBTM) lub porowatych (PA) bądź też z dodatkiem granulatu gumowego. W ostatnich latach powstało w kraju wiele odcinków, na których zastosowano technologie obniżające hałas drogowy. W artykule zaprezentowano wyniki badań ankietowych dotyczących intensywności zastosowania w Polsce różnych asfaltowych technologii drogowych obniżających hałas drogowy na drogach zarządzanych przez Generalną Dyrekcję Dróg Krajowych i Autostrad oraz przez zarządy dróg wojewódzkich.
\end{abstract}

Słowa kluczowe: hałas drogowy, cicha nawierzchnia, BBTM, asfalt porowaty

\section{WSTĘP}

Hałasem nazywa się wszelkie niepożądane, nieprzyjemne, dokuczliwe bądź szkodliwe drgania ośrodka sprężystego, działające na organ słuchu i inne zmysły oraz części organizmu człowieka. Transport drogowy, obok kolejowego, lotniczego oraz przemysłowego, jest głównym źródłem hałasu. Analiza dotycząca mapowania hałasu w Europie z 2009 roku wykazała, że w aglomeracjach o liczbie mieszkańców wyższej niż 250 tysięcy prawie 67 milionów osób jest narażonych na codzienny hałas drogowy przekraczający wartość $55 \mathrm{~dB}$ w ciagu dnia oraz prawie 48 milionów na hałas w nocy na wyższym poziomie niż $50 \mathrm{~dB}$ (wskaźnik dzienny, wieczorny i nocny $\left.-L_{d w n}\right)$ (Tracz i Bohatkiewicz, 2012; Practico i in., 2013).
Hałas drogowy może pochodzić z kilku źródeł, do których zalicza się: napęd pojazdu (silnik oraz rurę wydechową), aerodynamikę (turbulencje pojazdu) oraz kontakt opony z nawierzchnią. Dla pojazdów osobowych poruszających się ze stałą prędkością większą niż około $35 \mathrm{~km} \cdot \mathrm{h}^{-1}$ przeważającym źródłem hałasu jest hałas toczenia, natomiast dla pojazdów ciężkich granicę taką stanowi prędkość około $60 \mathrm{~km} \cdot \mathrm{h}^{-1}$ (Rasmussen, Bernhard, Sandberg i Mun, 2007).

Nawierzchnia drogi ma zatem istotny wpływ na poziom hałasu od ruchu samochodowego i w zależności od jej rodzaju może znacząco go obniżyć lub też wzmocnić (Descornet i Sandberg, 1980; Gardziejczyk, 2014). Rozwiązania stosowane w górnej warstwie nawierzchni w niektórych sytuacjach mogą także zastą-

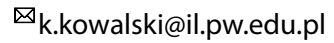


pić ekrany akustyczne, co w wielu przypadkach stanowi ograniczenie kosztów budowy drogi oraz ingerencji w otaczający ją krajobraz.

Stosowanie odpowiednich rozwiązań materiałowo-technologicznych do budowy górnych warstw nawierzchni ma na celu budowę nawierzchni w taki sposób, aby były one bezpieczne i komfortowe dla użytkowników oraz ograniczały negatywny wpływ na otoczenie (Sybilski i in., 2005; Bańkowski, 2011). Istnieje kilka rodzajów nawierzchni, które można stosować w celu obniżenia hałasu ruchu samochodowego i które wciąż są udoskonalane, by jak najlepiej spełniać założoną funkcję przy stosunkowo niskim nakładzie kosztów wbudowania oraz utrzymania (Christian i in., 2007; Kowalski, McDaniel, Shah i Olek, 2009). W Polsce przeprowadzono $\mathrm{w}$ ostatnich latach prace badawczo-wdrożeniowe w tym zakresie (Kowalski, Brzeziński, Król, Radziszewski i Szymański, 2015; Kowalski i in., 2016).

$\mathrm{W}$ artykule przedstawiono wyniki badań ankietowych dotyczących zastosowania w Polsce różnych asfaltowych technologii drogowych obniżających hałas drogowy na drogach zarządzanych przez Generalna Dyrekcję Dróg Krajowych i Autostrad oraz przez zarządy Dróg Wojewódzkich.

\section{ROZWIAZANIA MATERIALOWO- -TECHNOLOGICZNE NAWIERZCHNI OBNIŻAJĄCYCH HAŁAS NA DROGACH W POLSCE}

Informacje dotyczące stosowania nawierzchni obniżających hałas drogowy w Polsce zostały zebrane metodą ankietową wśród zarządców dróg krajowych oraz wojewódzkich. W ankietach pytano o doświadczenia związane ze stosowaniem asfaltowych nawierzchni drogowych umożliwiających obniżenie hałasu komunikacyjnego. W kilku przypadkach skontaktowano się także z zarządcami dróg miejskich. W celu całościowego ujęcia zagadnienia stosowania nawierzchni obniżających hałas drogowy w Polsce przeprowadzono wywiady z przedstawicielami działów technologii firm drogowych realizujących kontrakty drogowe w kraju. Uzyskano odpowiedzi od wszystkich oddziałów i centrali GDDKiA oraz wszystkich (poza dwoma) ZDW.
W tabeli przedstawiono średnią łączną długość wszystkich odcinków dróg zrealizowanych z zastosowaniem nawierzchni obniżających poziom hałasu komunikacyjnego. Na podstawie zebranego materiału można stwierdzić, że w Polsce występuje duża różnorodność rozwiązań materiałowo-technologicznych nawierzchni drogowych w warstwie ścieralnej. Do najczęściej stosowanych w Polsce rozwiązań umożliwiających obniżenie hałasu komunikacyjnego należy zaliczyć mieszanki mineralno-asfaltowe o nieciagłym uziarnieniu typu SMA, a następnie mieszanki o nieciągłym uziarnieniu o strukturze półotwartej (SMA-LA, BBTM), mieszanki $\mathrm{z}$ dodatkiem gumy i mieszanki o nieciagłym uziarnieniu o strukturze otwartej (PA). Należy zaznaczyć, że autorzy nie dokonywali oceny w zakresie efektywności stosowanej technologii, a decyzja o zakwalifikowaniu technologii jako „obniżajacej hałas" związana była z deklaracją zarządcy drogi.

Tabela. Zestawienie łącznej długości odcinków poszczególnych rodzajów mieszanki mineralno-asfaltowej wg deklaracji zarządców dróg (dane na podstawie badań ankietowych)

Table. Total length of various noise reducing pavements according to the road operator declaration (data based on survey)

\begin{tabular}{cc}
\hline $\begin{array}{c}\text { Rodzaj mieszanki } \\
\text { mineralno-asfaltowej }\end{array}$ & $\begin{array}{c}\text { Lączna długość } \\
\text { odcinków }\end{array}$ \\
\hline SMA & $\sim 270 \mathrm{~km}$ \\
\hline SMA-LA & $\sim 33 \mathrm{~km}$ \\
\hline BBTM & $\sim 113 \mathrm{~km}$ \\
\hline PA & $\sim 6 \mathrm{~km}$ \\
\hline Mieszanki z gumą & $\sim 90 \mathrm{~km}$ \\
\hline
\end{tabular}

\section{SMA i SMA-LA - mastyks grysowy}

Mastyks grysowy (SMA - ang. stone mastic asphalt) jest mieszanką mineralno-asfaltową wymagającą zagęszczenia, należącą do typu pośredniego o nieciągłym uziarnieniu, składającą się z dużej zawartości (około 60-80\%) grubego, łamanego kruszywa, związanego mastyksem. 
Warstwa ścieralna wykonana $\mathrm{z}$ mastyksu grysowego SMA charakteryzuje się przede wszystkim zwiększoną odpornością na odkształcenia trwałe w postaci kolein oraz odpornością na działanie czynników atmosferycznych, dlatego też stosowana jest jako warstwa ścieralna konstrukcji drogowej.

Mastyks grysowy o zwiększonej zawartości wolnych przestrzeni (SMA-LA - ang. split mastic asphalt, niem. Lärmarm) jest mieszanką mineralno-asfaltową stosowaną głównie w Niemczech.

Na drogach krajowych w Polsce w celu obniżenia hałasu komunikacyjnego stosuje się mieszankę mineralno-asfaltowa $\mathrm{z}$ mastyksu grysowego o maksymalnym uziarnieniu $8 \mathrm{~mm}$. Województwem, w którym najczęściej są stosowane nawierzchnie $\mathrm{z}$ tego typu mieszankami, jest województwo małopolskie, gdzie od 2010 roku powstało prawie $25 \mathrm{~km}$ dróg o nawierzchni z SMA 8. Należy stwierdzić, że wybudowane odcinki są obecnie $\mathrm{w}$ bardzo dobrym stanie i jedynie na jednym $\mathrm{z}$ nich zauważono niewielkie uszkodzenia w postaci lokalnych spękań. W województwach lubelskim oraz podlaskim powstało około $11 \mathrm{~km}$ nawierzchni $\mathrm{z}$ mastyksu grysowego, które również są w dobrym stanie. Jedynie w obrębie skrzyżowań typu ronda, w szczególności na dojeździe do skrzyżowania, występują miejscowe deformacje.

Spośród dróg wojewódzkich najwięcej odcinków, na których warstwa ścieralna nawierzchni wykonana została z SMA 8, znajduje się w województwie warmińsko-mazurskim, gdzie $\mathrm{w}$ okresie niespełna 3 lat (2013-2015) powstało około $70 \mathrm{~km}$ dróg o „cichej” nawierzchni z mastyksu grysowego. Jak pokazują badania ankietowe, $w$ województwie warmińsko-mazurskim mieszankę o maksymalnym uziarnieniu $8 \mathrm{~mm}$ stosowano na drogach na terenie zabudowanym, natomiast mieszanke o maksymalnym uziarnieniu $11 \mathrm{~mm}$ - na terenie niezabudowanym, co mogło wynikać z potrzeby obniżenia hałasu w obszarach zabudowanych. Zastosowanie kruszywa o mniejszym maksymalnym wymiarze ziaren skutkuje większym obniżeniem hałasu. Wybudowane odcinki prawidłowo spełniaja założone cele, obniżając poziom hałasu w otoczeniu dróg, a ich stan oceniany jest przez zarządców drogi jako zadowalający. W pozostałych województwach, w których zastosowano ten rodzaj technologii, odcin- ki także są w dobrym stanie i w zależności od regionu uzyskano większe lub mniejsze obniżenie poziomu hałasu drogowego.

Mastyks grysowy o maksymalnym uziarnieniu $5 \mathrm{~mm}$ nie jest rozwiązaniem powszechnie stosowanym w Polsce. Nawierzchnia SMA 5 powstała w województwie małopolskim w 2014 roku wykazuje rozszczelnienie połączeń technologicznych oraz spękania warstwy ścieralnej, natomiast podobna nawierzchnia wybudowana na terenie województwa pomorskiego w 2015 roku nadal wykazuje stan dobry. Taki stan rzeczy może świadczyć jedynie o różnych warunkach klimatycznych występujących na północy oraz na południu kraju, które mają znaczący wpływ na stan nawierzchni.

Warstwa ścieralna nawierzchni drogowej wykonana z mastyksu grysowego o zwiększonej zawartości wolnych przestrzeni (SMA-LA) jak dotąd wykonywana była wyłącznie w województwie wielkopolskim, zarówno na drogach krajowych, jak i wojewódzkich. Ponad $30 \mathrm{~km}$ wybudowanych odcinków dróg na chwilę obecną jest $\mathrm{w}$ bardzo dobrym stanie pomimo stosunkowo długiego czasu użytkowania, wynoszacego około 8 lat. Pomiary wykonane w ciagu drogi wojewódzkiej 184 wykazały niewielkie przekroczenia dopuszczalnego poziomu hałasu w porze dziennej oraz znaczne przekroczenia $\mathrm{w}$ porze nocnej najprawdopodobniej wynikające $\mathrm{z}$ dużej prędkości poruszających się pojazdów.

W celu obniżenia poziomu hałasu w najbliższym czasie planowana jest budowa odcinka drogi ekspresowej S6 z zastosowaniem nawierzchni SMA-LA.

$\mathrm{W}$ podsumowaniu badań ankietowych należy stwierdzić, że zastosowanie technologii SMA/SMA-LA w celu obniżenia hałasu toczenia miało miejsce na 27 odcinkach dróg w zarządzie GDDKiA oraz na 30 odcinkach dróg z zarządzie ZDW.

\section{BBTM - beton asfaltowy do bardzo cienkich warstw}

Beton asfaltowy do bardzo cienkich warstw (BBTM - fr. beton bitumineuse trés mince) jest mieszanką mineralno-asfaltową zagęszczalną, typu pośredniego o nieciagłym uziarnieniu i otwartej lub półotwartej strukturze. Beton asfaltowy do bardzo cienkich warstw 
stosowany jest w Polsce od 2014 roku w szczególności w województwie małopolskim, gdzie przez 3 lata powstało ponad $100 \mathrm{~km}$ dróg o tego typu nawierzchni. Na podstawie badań ankietowych należy stwierdzić, że na wybudowanych odcinkach występują spękania podłużne w rejonie studzienek kanalizacyjnych, wpustów ulicznych, ścieków przykrawężnikowych oraz w obrębie krawędzi jezdni i zatok autobusowych. Ponadto stwierdzono występowanie zniszczeń w postaci rozszczelnienia spoin technologicznych oraz ubytków kruszywa. Analizując zniszczenia nawierzchni, można przypuszczać, że były one spowodowane niewłaściwym doborem rodzaju nawierzchni do struktury ilościowej oraz rodzajowej ruchu. Uszkodzenia powstałe po tak krótkim czasie eksploatacji mogą świadczyć również o złym doborze lepiszcza asfaltowego bądź też nieprawidłowym utrzymaniu zimowym nawierzchni.

Warstwe ścieralna z BBTM 8 zastosowano również przy budowie obwodnicy Brodnicy w 2016 roku w województwie kujawsko-pomorskim. Stan nawierzchni tej obwodnicy został określony jako dobry i po czasie eksploatacji, obejmującym okres zimowy, nie stwierdzono uszkodzeń.

$\mathrm{Z}$ badań ankietowych wynika, że zastosowanie technologii BBTM w celu obniżenia hałasu toczenia miało miejsce na 1 odcinku drogi krajowej oraz na 16 odcinkach dróg wojewódzkich.

\section{PA - asfalt porowaty}

Asfalt porowaty (PA - ang. porous asphalt) jest mieszanką mineralno-asfaltową zagęszczalną, typu pośredniego o nieciagłym uziarnieniu, charakteryzującą się dużą zawartością frakcji grysowej (około 80-90\%) oraz dużą zawartością połączonych ze sobą wolnych przestrzeni. Warstwa nawierzchni wykonana $\mathrm{z}$ tej mieszanki ma właściwości drenażowe oraz zdolność do pochłaniania części fal akustycznych powstających na styku opona/nawierzchnia.

Asfalt porowaty, ze względu na niekorzystne warunki klimatyczne w Polsce oraz wysokie wymagania w zakresie utrzymania, jest najmniej rozpowszechnionym rozwiązaniem materiałowo-technologicznym stosowanym do budowy górnej warstwy nawierzchni. Na terenie Polski od 2010 roku powstało nieco ponad $5 \mathrm{~km}$ nawierzchni porowatej, z czego 1 odcinek znajdujący się w województwie małopolskim po okresie
5 lat użytkowania został rozebrany. Stan pozostałych odcinków określono jako dobry oraz zwrócono uwagę na skuteczność zastosowanego rozwiązania.

$\mathrm{Z}$ badań ankietowych wynika, że eksploatacja nawierzchni $\mathrm{z}$ asfaltu porowatego stwarza wiele trudności między innymi ze względu na konieczność dość częstego (maksymalnie co 2 lata) czyszczenia górnej warstwy nawierzchni wyspecjalizowanym, trudno dostępnym w Polsce sprzętem. Czyszczenie powinno odbywać się z wykorzystaniem wody pod ciśnieniem i sprężonego powietrza. W zakresie utrzymania zimowego wymagane jest użycie do odśnieżania pługów $\mathrm{z}$ gumowym fartuchem zabezpieczającym lemiesz oraz stosowanie zwiększonej ilości soli lub solanki. Zabiegi utrzymaniowe są niezbędne $\mathrm{w}$ zapobieganiu zanieczyszczenia skanalizowanych porów nawierzchni, a co za tym idzie pogorszenia właściwości drenażowych i akustycznych nawierzchni.

$\mathrm{Na}$ podstawie badań ankietowych potwierdzono zastosowanie technologii asfaltu porowatego $\mathrm{w}$ celu obniżenia hałasu toczenia na 1 odcinku drogi krajowej oraz na 2 odcinkach dróg wojewódzkich.

\section{Nawierzchnia z dodatkiem gumy}

Mieszanka mineralno-asfaltowa $\mathrm{z}$ dodatkiem gumy jest mieszanka, do której został wprowadzony granulat gumowy. Istnieją 2 metody wprowadzania granulatu gumowego do mieszanki: na sucho oraz na mokro. Metoda na sucho polega na dodaniu do mieszanki mineralnej granulatu gumowego $\mathrm{w}$ celu zastąienia części kruszywa, natomiast metoda na mokro polega na wcześniejszym modyfikowaniu lepiszcza miałem gumowym i wprowadzeniu gotowego lepiszcza gumowo-asfaltowego do mieszanki mineralnej (Radziszewski i in., 2017).

$\mathrm{Z}$ badań ankietowych wynika, że nawierzchnie $\mathrm{z}$ dodatkiem rozdrobnionej gumy do końca XX wieku, poza odcinkami doświadczalnymi, nie były wykonywane w Polsce. Po 2000 roku wzrosło zainteresowanie tą technologią ze względu między innymi na konieczność utylizacji zużytych opon samochodowych zgodnie ze zwiększonymi wymaganiami ochrony środowiska. Początkowo stosowano technologię modyfikacji mieszanek mineralno-asfaltowych dodatkiem granulatu gumowego $\mathrm{z}$ recyklingu zużytych opon samochodowych metodą na sucho. Ten rodzaj 
mieszanki mineralno-gumowo-asfaltowej był zastosowany do budowy nawierzchni przede wszystkim w województwie wielkopolskim. Kilka odcinków po bardzo krótkim czasie eksploatacji, wynoszącym okoto 2-3 lata, zostało następnie sfrezowanych ze względu na zły stan spowodowany uszkodzeniami w okresie zimowej eksploatacji.

W związku z pojawieniem się w Polsce urządzeń do modyfikacji asfaltów miałem gumowym w technologii na mokro nastapił rozwój technologii nawierzchni z lepiszczem gumowo-asfaltowym. Tego typu technologie stosowano i stosuje się obecnie w całym kraju, a szczególnie dużo realizacji miato miejsce na terenie województw dolnośląskiego oraz mazowieckiego. Przykładem udanej inwestycji $\mathrm{z}$ zastosowaniem do warstwy ścieralnej nawierzchni lepiszcza gumowo-asfaltowego jest ul. Wołoska w Warszawie. Nawierzchnia wykonana w 2015 roku z mieszanki BBTM z lepiszczem o zawartości dodatku gumowego w ilości $17 \%$ jest po 3 latach eksploatacji w bardzo dobrym stanie.

Na podstawie wyników badań ankietowych i dotychczasowych doświadczeń można stwierdzić, że najlepszym rozwiązaniem materiałowo-technologicznym w zakresie obniżenia hałasu toczenia w warunkach klimatycznych Polski oraz pod względem trwałości jest zastosowanie mieszanek o nieciagłym uziarnieniu typu BBTM z lepiszczem gumowo-asfaltowym.

\section{DOŚWIADCZENIA KRAJOWE W STOSOWANIU NAWIERZCHNI OBNIŻAJĄCYCH HAŁAS DROGOWY}

Wyniki badań ankietowych wykonanych wśród zarządców dróg krajowych oraz wojewódzkich zostały opracowane w formie map pokazujących zróżnicowanie pod względem zastosowanej technologii i występowania odcinków dróg w poszczególnych województwach z nawierzchnią, obniżającą hałas komunikacyjny. Przedstawione na mapach obszary województw są zróżnicowane jedynie w skali względnej, tj. brak zastosowań, nieliczne odcinki dróg z nawierzchnią ,cichą”, stosunkowo duża liczba dróg $\mathrm{z}$ tą nawierzchnią.

Należy podkreślić, że opracowane mapy nie uwzględniały informacji o nawierzchniach „cichych” wykonanych na drogach gminnych i powiatowych.

\section{Drogi krajowe}

Zróżnicowanie występowania odcinków dróg o nawierzchniach obniżających poziom hałasu drogowego, zarządzanych przez Generalną Dyrekcję Dróg Krajowych i Autostrad, przedstawiono na rysunku 1 . Z rysunku wynika, że najwięcej zastosowań nawierzchni „cichych” występuje w województwie wielkopolskim, mniej na zachodzie i w centralnej części kraju. Na północno-zachodnim obszarze Polski wystepuje niewiele odcinków nawierzchni drogowej, które mają na celu obniżenie hałasu drogowego. Oddziały GDDKiA warmińsko-mazurskie, opolskie, śląskie i podkarpackie nie przedstawiły w ankiecie przykładów $\mathrm{z}$ nawierzchniami „cichymi”.

Na rysunku 2 przedstawiono mape Polski z województwami zróżnicowanymi pod względem zastosowanych rozwiązań materiałowo-technologicznych w zakresie nawierzchni obniżających hałas toczenia na drogach krajowych. Klasyczne rozwiązanie z użyciem mastyksu grysowego (SMA) ma zastosowanie w szczególności na wschodzie oraz na południu kraju, natomiast użycie mieszanek mineralno-asfaltowych modyfikowanych gumą przeważa w zachodniej części Polski. Asfalt porowaty (PA) oraz beton asfaltowy do bardzo cienkich warstw (BBTM) występują na kilku odcinkach w środkowej Polsce.

\section{Drogi wojewódzkie}

Zróżnicowanie występowania odcinków dróg o nawierzchniach obniżających poziom hałasu drogowego, zarządzanych przez zarządców dróg wojewódzkich, przedstawiono na rysunku 3 . Z rysunku wynika, że najczęściej nawierzchnie „ciche” stosuje się w województwach warmińsko-mazurskim oraz małopolskim. Zarządy dróg wojewódzkich: zachodnio-pomorskie, kujawsko-pomorskie, podlaskie, łódzkie oraz śląskie, nie przedstawiły $w$ ankiecie przykładów zastosowania nawierzchni „,cichych”. Jak wynika z badań ankietowych, na pozostałym obszarze Polski tego typu rozwiązania stosowane są sporadycznie.

$\mathrm{Na}$ rysunku 4 przedstawiono mape Polski z województwami zróżnicowanymi pod względem zastosowanych rozwiązań materiałowo-technologicznych w zakresie nawierzchni obniżających hałas toczenia na drogach wojewódzkich. Klasyczne rozwiązanie z użyciem mastyksu grysowego (SMA) pojawia się, 


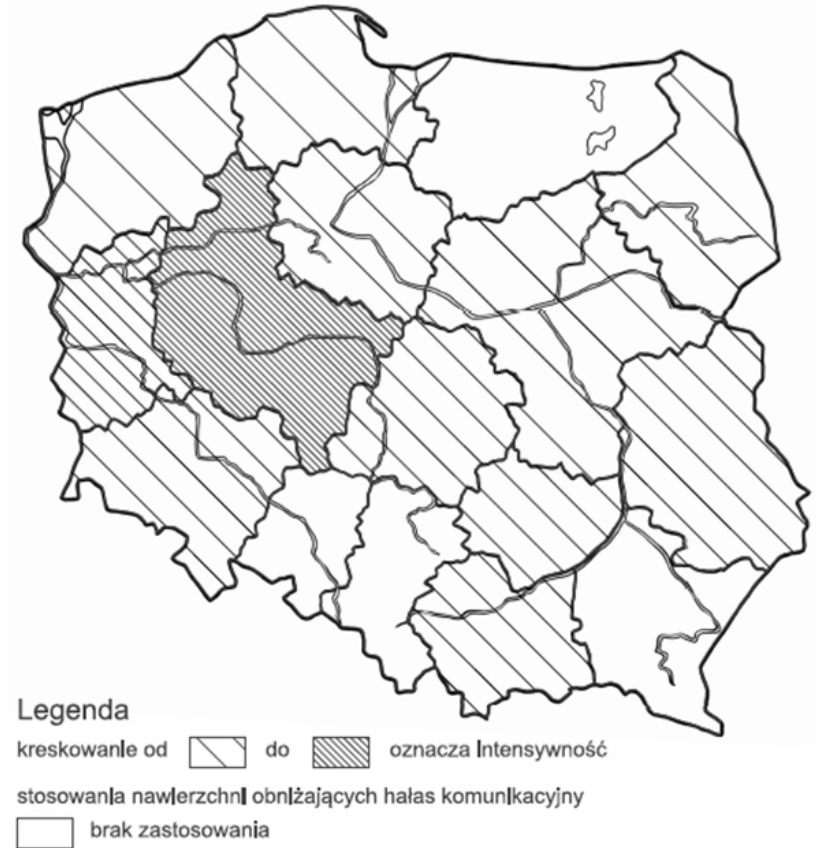

Rys. 1. Zróżnicowanie stosowania nawierzchni obniżających hałas na drogach krajowych

Fig. 1. National roads: diversity in noise reducing pavement technologies

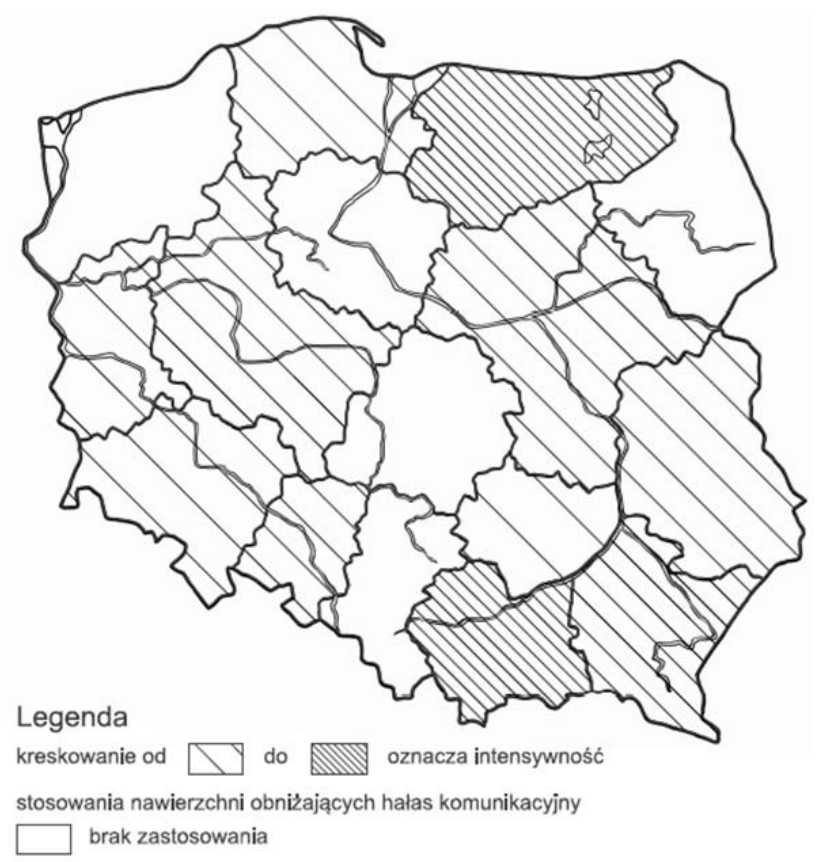

Rys. 3. Zróżnicowanie stosowania nawierzchni obniżających hałas na drogach wojewódzkich

Fig. 3. Voivodships roads: diversity in noise reducing pavement technologies

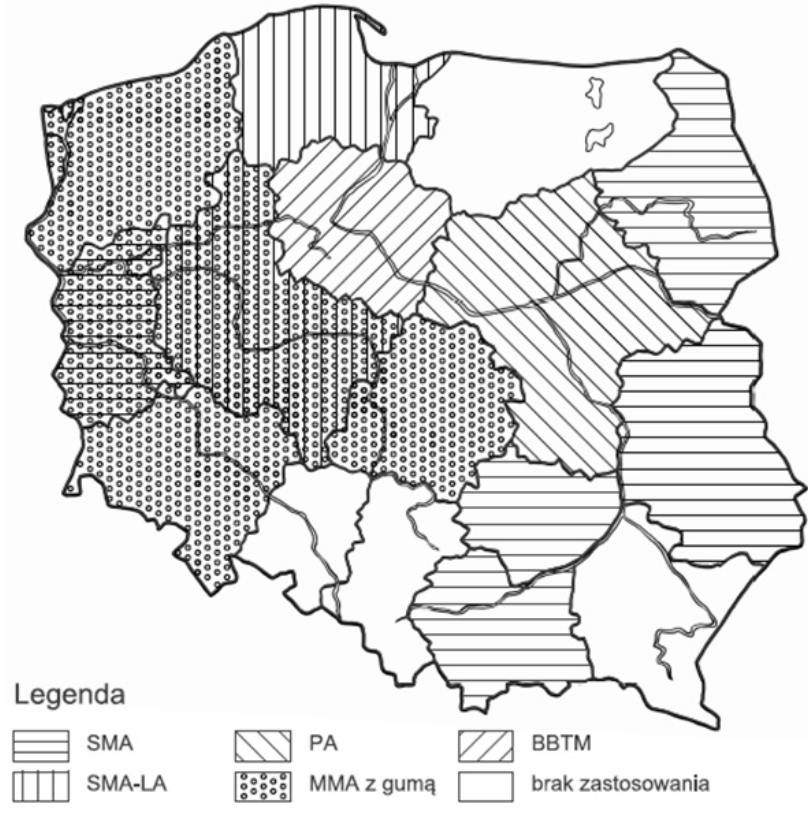

Rys. 2. Rodzaje rozwiązań materiałowo-technologicznych mieszanek mineralno-asfaltowych do nawierzchni obniżających poziom hałasu na drogach krajowych

Fig. 2. Types of asphalt mixtures reducing noise used in national roads

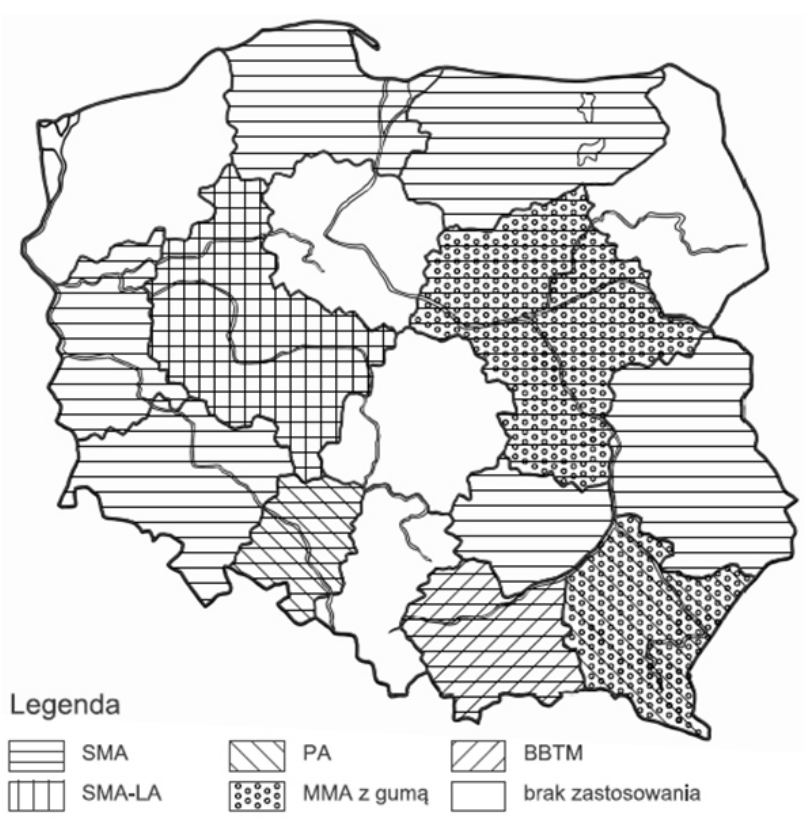

Rys. 4. Rodzaje rozwiązań materiałowo-technologicznych mieszanek mineralno-asfaltowych do nawierzchni obniżających poziom hałasu na drogach wojewódzkich

Fig. 4. Types of asphalt mixtures reducing noise used in voivodships roads 
oprócz Podkarpacia, we wszystkich województwach, gdzie zastosowano nawierzchnie „,iche”, co potwierdza popularność tej technologii. W województwie mazowieckim, na drodze pozostającej w gestii Zarządu Miejskich Inwestycji Drogowych w Warszawie, powstały 2 odcinki o warstwie ścieralnej $\mathrm{z}$ betonu asfaltowego do bardzo cienkich warstw (BBTM) z dodatkiem lepiszcza gumowo-asfaltowego.

\section{PODSUMOWANIE}

W ostatnich latach świadomość społeczeństwa na temat szkodliwości hałasu drogowego nabiera coraz większego znaczenia. Dotychczasowe negatywne doświadczenia $\mathrm{z}$ hałasem oraz badania naukowe przyczyniły się do innego podejścia do kwestii oddziaływania hałasu na środowisko, w szczególności zdrowia ludzi oraz komfortu ich życia codziennego (Bendtsen i Gspan, 2017). Polska jest krajem, który w ostatnich latach intensywnie rozwija swój układ komunikacyjny w ramach polityki spójności Unii Europejskiej, wprowadzając również nowe rozwiązania materiałowo-technologiczne nawierzchni drogowych w celu obniżenia poziomu hałasu. Badacze, projektanci oraz inwestorzy coraz częściej sięgają po nowe rozwiązania z zakresu nawierzchni „,cichych” w celu ich ulepszania oraz dostosowywania do warunków klimatycznych panujących w naszej strefie klimatycznej.

Na rysunku 5 przedstawiono udział poszczególnych województw we wdrożeniu rozwiązań mających na celu obniżenie poziomu hałasu zarówno na drogach krajowych, jak i wojewódzkich. Zestawienie powstało na podstawie szacowanej liczby odcinków nawierzchni „cichej”. Można stwierdzić, że najwięcej odcinków dróg z nawierzchnią ograniczającą hałas komunikacyjny występuje w województwie wielkopolskim $(30 \%)$, a następnie w województwach warmińsko-mazurskim $(16 \%)$, małopolskim $(15 \%)$ oraz podkarpackim $(7 \%)$. Dominujaca technologia obniżająca poziom hałasu drogowego w tych województwach sa: SMA, SMA-LA oraz mieszanki mineralno-gumowo-asfaltowe.

Nawierzchnie „ciche” sa efektywnym rozwiązaniem materiałowo-technologicznych w przypadku konieczności obniżenia poziomu hałasu w otoczeniu dróg, jednak ograniczone doświadczenie w zakresie ich zastosowania w Polsce stanowi podstawową bariere

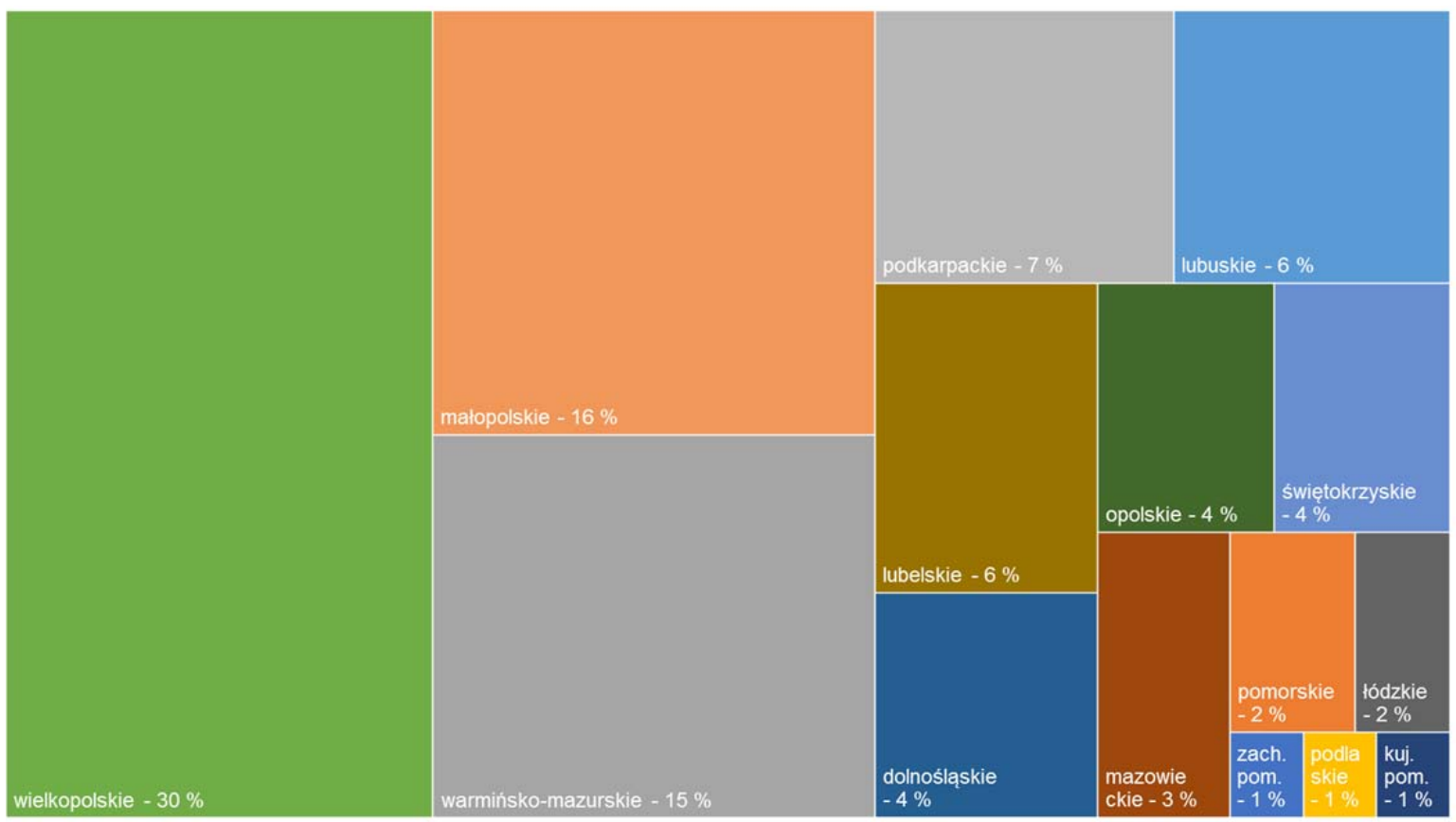

Rys. 5. Udział poszczególnych województw Polski w zastosowaniu nawierzchni obniżających hałas drogowy

Fig. 5. Poland splitted for voivodships in terms of application of noise reducing pavements 
Załęska-Dobkowska, K., Kowalski, K.J., Król, J., Radziszewski, P., Sarnowski, M. (2018). Nawierzchnie obniżające hałas drogowy - doświadczenia krajowe i kierunki rozwoju. Acta Sci. Pol. Architectura, 17 (4), 19-27. doi: 10.22630/ASPA.2018.17.4.37

rozwoju tego typu technologii. Najskuteczniejsze rozwiązania, takie jak asfalt porowaty lub doświadczalne nawierzchnie poro-elastyczne, nie zawsze sprawdzają się w zróżnicowanych warunkach klimatycznych, a ich prawidłowe utrzymanie wymaga od zarządców dróg czyszczenia ciśnieniowego z użyciem specjalistycznego sprzętu oraz specjalnego utrzymania zimowego.

Wybór technologii nawierzchni obniżającej hałas drogowy związany jest najczęściej ze wzrostem kosztów wykonania nawierzchni. Biorąc jednak pod uwage wyniki prowadzonych na świecie analiz kosztów cyklu życia tego typu nawierzchni, można stwierdzić, że mogą to być rozwiązania porównywalne pod względem finansowym do innych rozwiązań ograniczających hałas komunikacyjny, np. ekranów akustycznych. Najbardziej skutecznym sposobem ograniczenia hałasu toczenia jest podejście kompleksowe łączące technologię nawierzchni, zagadnienia inżynierii ruchu oraz ekrany akustyczne. Ważnym czynnikiem wspomagającym rozwój technologii nawierzchni ,cichych” jest także świadomość inwestorów dotycząca nie tylko kosztów związanych z samą inwestycja, ale również kosztów społecznych, związanych z oddziaływaniem hałasu drogowego.

Nawierzchnie z mastyksu grysowego oraz z dodatkiem rozdrobnionej gumy są obecnie najczęściej stosowanym $\mathrm{w}$ Polsce rozwiązaniem, zarówno na drogach krajowych, jak i wojewódzkich w celu obniżenia poziomu hałasu toczenia. Nawierzchnie te nie wymagają specjalnego utrzymania w czasie eksploatacji. Opracowano również rozwiązania specjalne stosowane przez firmy zajmujące się produkcją i wbudowaniem mieszanek mineralno-asfaltowych. Do takich rozwiązań materiałowo-technologicznych należy mieszanka BBTM z lepiszczem gumowo-asfaltowym do nawierzchni ,cichych”.

Należy stwierdzić, że w Polsce następuje stopniowy i konsekwentny rozwój technologii nawierzchni obniżających hałas drogowy.

\section{Podziękowania}

Artykuł powstał dzięki wsparciu finansowemu Generalnej Dyrekcji Dróg Krajowych i Autostrad oraz Narodowego Centrum Badań i Rozwoju w ramach programu RID w projekcie RID-I-76. Upowszech- nianie wyników badań było możliwe dzięki dotacji statutowej Ministerstwa Nauki i Szkolnictwa Wyższego.

\section{PIŚMIENNICTWO}

Bańkowski, W. (2011). Ciche nawierzchnie drogowe na świecie. Materiały Budowlane, 11, 51-53.

Bendtsen, H. \& Gspan, K. (2017) Technical Report 2017-01 State of the art. In managing road traffic noise: noisereducing pavements. Conference of European Directors of Roads, January.

Christian, A. i inni (2007). Low-noise road surfaces in urban areas, final report. FEDRO, Switzerland.

Descornet, G. \& Sandberg, U. (1980). Road Surface Influence on Tire / Road Noise - Part II. Proceedings of the Inter-Noise 80 Conference, December 8-10, Miami, Florida.

Gardziejczyk, W. (2014) „Cicha” nawierzchnia drogowa jako sposób na ograniczenie poziomu hałasu od ruchu samochodowego". Inżynieria Ekologiczna, 40, 65-73. Białystok: Politechnika Białostocka.

Kowalski, K. J., Bańkowski, W., Król J. B., Gajewski, M., Horodecka, R. \& Świeżewski, P. (2016). Selection of quiet pavement technology for Polish climate conditions on the example of CiDRO project. Transportation Research Procedia, 14, 2724-2733. Proceedings of 6th Transport Research Arena, April 18-21. Warsaw.

Kowalski, K. J., McDaniel, R. S., Shah, A. \& Olek, J. (2009). Long-Term Monitoring of Noise and Frictional Properties of Three Pavements: Dense-Graded Asphalt, Stone Matrix Asphalt, and Porous Friction Course. Transportation Research Record (TRR). Journal of the Transportation Research Board, 2127, 12-19.

Kowalski, K. J., Brzeziński, A. J., Król, J. B., Radziszewski, P. \& Szymański, Ł. (2015). Traffic analysis and pavement technology as a tool for urban noise control. Archives of Civil Engineering, 4, 61, 107-125.

Pratico, F. G., Swanlund, M., George, L. A., Anfosso, F., Tremblay, G., Tellez, R., Kamiya K. \& Cerro J. (2013). Quiet pavement technologies. World Road Association (PIARC), France.

Radziszewski, P., Sarnowski, M., Król, J. B., Kowalski, K. J., Ruttmar, I. \& Zborowski A. (2017). Właściwości asfaltów modyfikowanych guma i mieszanek mineralnogumowo-asfaltowych. Warszawa: Wydawnictwa Komunikacji i Łączności.

Rasmussen, R. O., Bernhard, R. J., Sandberg, U. \& Mun, E. P. (2007). The Little Book of Quiter Pavements. Washinghton: U.S. Department of Transportation. 
Sybilski, D. i inni (2005). Ocena wpływu typu i technologii wykonania nawierzchni drogowej na hałaśliwość ruchu drogowego i jego uciążliwość dla środowiska. Temat WS-05. Warszawa: Instytut Badawczy Dróg i Mostów.
Tracz, M. \& Bohatkiewicz, J. (2007). Selected problems of noise protection - suggestions of changes in law regulations and strategies. TransNoise, Zakopane.

\title{
NOISE REDUCING PAVEMENTS - NATIONAL EXPERIENCES AND DEVELOPMENTS
}

\begin{abstract}
Road noise is an important problem in environment protection and transportation network development. In addition to vehicle engine and aerodynamic, it is also related to tire/pavement interaction, especially once the vehicle speed exceeds $50 \mathrm{~km} \cdot \mathrm{h}^{-1}$. Application of special material and technological solutions can help to limit that noise. In order to meet this goal, pavement surface layers are constructed with asphalt mixtures such as stone mastic asphalt (SMA) with fine gradation or with higher air voids content (SMA-LA and BBTM), porous asphalt (PA) and mixes with asphalt rubber. Recently various road sections in Poland were constructed with asphalt technologies lowering tire/pavement noise.

This paper presents results of survey dealing with intensity of noise reducing pavements application in Poland in roads operated by General Directorate for National Roads and Motorways and administrators of voivodeship roads.
\end{abstract}

Key words: road noise, quite pavements, BBTM, porous asphalt 